\title{
Benefits of Triple Bottom Line Disclosures on Corporate Performance: An Exploratory Study of Corporate Stakeholders
}

\author{
C. M. Ekwueme ${ }^{1}$, C. F. Egbunike ${ }^{1} \&$ C. I. Onyali ${ }^{1}$ \\ ${ }^{1}$ Department of Accountancy, Faculty of Management Sciences, Nnamdi Azikiwe University, Nigeria \\ Correspondence: C. M. Ekwueme, Department of Accountancy, Faculty of Management Sciences, Nnamdi \\ Azikiwe University, P.M.B. 5025, Awka, Anambra State, Nigeria. E-mail: cm.ekwuemecm@unizik.edu.ng
}

Received: November 14, 2012 Accepted: February 20, 2013 Online Published: March 13, 2013

doi:10.5539/jms.v3n2p79 URL: http://dx.doi.org/10.5539/jms.v3n2p79

\begin{abstract}
Advocates of CSR argue that transparency and accountability are essential components of a successful sustainability strategy. In this context, sustainability reporting is one such tool for communicating organisational performance with respect to organisational CSR practices. This empirical paper examines the connection between such reporting practices and corporate performance from a stakeholder perspective. Using a sample of 141 respondents, comprising 21 corporate managers; 55 corporate employees and 65 consumers and investors, this study examined the connection between sustainability reporting and corporate performance. Four hypotheses were formulated and tested in the study. In addition to descriptive statistics, Kolmogorov-Smirnov (K-S), One Sample t-test and Multiple Regression Technique (MRT) were used in analyzing the primary data. The results of the data analysis showed a positive connection between sustainability reporting and corporate performance. Both consumers and investors were inclined to product purchase of green corporations. This would have the dual effect of increased market share and market capitalization of the companies. Employees were inclined to work in green corporations safeguarding their interests and healthy work environment. And corporate managers agreed that cost of recycling was generally cheaper than new purchase. Based on this, the study recommends the adoption of sustainability reports for organisations seeking sustainable corporate performance. The improved transparency and accountability levels of traditional financial reports through inclusion of TBL principles could serve as a labyrinth safeguarding corporations against legal hassle and surmounting stakeholder pressure. Thus, ultimately leading to improved market share, improved employee motivation and reduced labour turnover in such organisations.
\end{abstract}

Keywords: Triple Bottom Line (TBL), Triple Bottom Line Reporting (TBLR)

\section{Introduction}

Corporate social responsibility started to spread more dramatically towards the end of the $20^{\text {th }}$ century when worries about the environment were beginning to grow (Stanislavská, Margarisová \& Štastná, 2010), especially in connection with climatic changes, pollution, habitat loss, overexploitation of species, and the spread of invasive species or genes (Reddy \& Gordon, 2010), which led to the development of environmental reporting (Stanislavská et al., 2010). Thus, Waddock et al. (2002, cited in Miller, Buys \& Summerville, 2007) believe one of the greatest pressures on businesses today is to be socially accountable. Corporate responsibility is often regarded as a response to the imbalances resulting from the acceleration of the globalization process and the underdeveloped international governance systems on environmental and social issues when compared to those for economic governance (Zadek, 2004, cited in Da Piedade \& Thomas, 2006). To cope up with the globalized challenges, corporate all around the globe wants to consider applying a corporate sustainability plan by addressing their "Triple Bottom Line Reporting" which includes paying close attention to their economic (financial factors), environmental (risk and requirement factors) and social (human factors) issue (Dutta et al., 2011).

The idea behind the triple bottom line paradigm is that a corporation's ultimate success or health can and should be measured not just by the traditional financial bottom line, but also by its social/ethical and environmental performance (Norman and MacDonald, 2003). Requiring companies to report on a regular basis regarding the impact their activities have had on the environment will allow: (a) stakeholders to be informed of the nature of activities companies are engaged in; (b) stakeholders to monitor the effect such activities are having on their 
environment; and (c) companies in consultation with the relevant stakeholders will be able to implement strategies to minimize the effect of such activities (Reddy \& Gordon, 2010).

The outcome of management processes, from strategic planning to implementation of the plan, underpins the measurement of corporate performance (Fauzi et al., 2010). Gavrea et al. (2011) noted the importance of measuring corporate performance in the following statement:

Knowing the determinants of organizational performance is important especially in the context of the current economic crises because it enables the identification of those factors that should be treated with an increased interest in order to improve organizational performance.

Corporate performance usually delineated in financial reports, is a legal requirement for organizations across the world (Hubbard, 2008). Traditionally, annual reports have served as a medium to inform stakeholders about the accounting and economic performance of the corporation (Finch, 2005, cited in Reddy \& Gordon, 2010). Throughout the world, publicly held corporations control and transform natural and social resources into economic goods and services (Brown et al., 2006). Publicly available information is a necessary, though not sufficient, prerequisite for responsible resource stewardship and management (Brown et al., 2006). As corporations play an integral part in both intermediate and final production and consumption, it is postulated that sustainable production and consumption of resources by corporations would lead to an improvement in the environment and also reduce its associated side effects (Global Reporting Initiative (GRI), 2004, cited in Reddy \& Gordon, 2010).

Thus, the relevance and integrity of information contained in, and made available by, measurement and accountability systems holds a place of central importance in our ability to hold accountable those granted the responsibility for society's resources (Brown et al., 2006). However, most corporate reports focus mainly on shareholders, thus reflecting the views of early economists such as Milton Friedman who opined 'that corporations should not confuse corporate issues with societal obligations, but rather focus on its core objective of profit maximization' (Friedman, 1970). Fauzi et al. (2010) noted the underlying limitation in defining corporate performance in terms of 'bottom line' (economic) reports in the following statement:

'Not only does the corporate performance imbalance the financial aspect and non-financial aspect, but the performance also does not accommodate other parties outside the market system'.

This singular approach to corporate performance through the exclusion of other parties outside the market system creates a monolithic image of other varying stakeholders (such as: consumers, employees, etc.) facing the organisation. PwC (2002, cited in Robins, 2006) once commented:

'With the current breakdown of confidence in financial reporting, large companies are facing increasing demands and expectations from stakeholders and are being held more accountable for their performance and actions. The TBL approach is a proactive step in providing shareholders with increased transparency and a broader framework for decision making ... it's a great way for companies to disclose meaningful non-financial results'.

Chatterjee (2005, cited in Dutta et al., 2011) noted that, the advent of the TBL paradigm aims at encouraging managers to think beyond the old-fashioned financial bottom line, in terms of two additional 'bottom lines', namely the 'social bottom line' and 'environmental bottom line'. Thus, Swinson (2002, cited in Osisioma, 2010) opined that 'We live and die at the whims of market forces that will show no mercy if we do not provide what the markets require of us'. In this context, TBLR reflects a corporation's greater transparency and accountability in its public reporting, communication and disclosure with regard to how the corporate entity performs in its environmental, social and economic dimensions (Lewis, 2011). If managers are held accountable for the social and environmental impact of their decisions through external reporting of results in these areas, thus they will of necessity more fully incorporate them into their decision processes (Dutta et al., 2011). Thus, identifying possible trade-offs between disclosure of social, environmental and economic activities encourage managers to more fully incorporate sustainability practices in to their corporate strategy. To specifically assess the impact of sustainability reporting on corporate performance, the following research questions were formulated:

1) To what extent would triple bottom line disclosures in financial statements influence product consumption behaviour and investment choice among studied respondents?

2) To what extent would triple bottom line disclosures in financial statements mitigate litigation risks posed by social and environmental claims on a company?

3) To what extent would triple bottom line disclosures in financial statements improve employee motivation, with a view to reduce labour turnover in organisations? 
4) To determine whether corporate sustainability practices, such as: waste recycling, reduced and controlled $\mathrm{CO} 2$ emissions, and selection of green suppliers' lower operating costs for sustainable firms.

This empirical paper is organized as follows: the first section reviews the path to triple bottom line reporting as well issues underlying the triple bottom line concept; the second outlines various definitions of the concept; the third is a brief review of corporate performance perspectives; the fourth and fifth details the empirical data analysis procedure as well as discussion of findings, conclusion and recommendations.

\section{Literature Review}

\subsection{The Path to Triple-Bottom-Line Reporting}

In the 1960's and 1970's there was a widespread, although by no means dominant, recognition that human activities, including corporate activities, had great and potentially disastrous impacts on the natural environment (Brown et al., 2006). Corporate social responsibility emerged in the late 1980s as a label for a philosophy of economic growth in business that values only those gains that can endure into future generations (Casanova, 2010). Grayson and Hodges (2001, cited in Da Piedade \& Thomas, 2006) point to the interaction of four forces or signposts that make corporate responsibility a mainstream business issue, namely: 1) the development of technology and communications which result in companies 'having no place to hide'; 2) the increased prominence of multinationals globally and the growth in the value and visibility of their brands which make them more susceptible to scrutiny; 3 ) demographic change and development which encompasses issues such as an ageing population in the developed world, skewed income distribution, limited access to health, education and jobs; and 4) the revolution of values and the decline in deference for institutions. As society began to demand cleaner water, cleaner air, fewer toxins, and the other benefits of environmentally thoughtful stewardship, corporations, however reluctantly, initiated improvements in their environmental behaviour (Hoffman, 2000, cited in Brown et al., 2006). The table below presents different CSR models as postulated by various scholars at varying times.

Table 1. Brief review of corporate social responsibility models

\begin{tabular}{|c|c|c|}
\hline Authors & Definition of CSR & CSR Dimensions \\
\hline $\begin{array}{l}\text { Carroll } \\
(1979)\end{array}$ & $\begin{array}{l}\text { The articulation and interaction between (a) } \\
\text { different categories of social responsibilities; } \\
\text { (b) specific issues relating to such } \\
\text { responsibilities; and (c) the philosophies of the } \\
\text { answers }\end{array}$ & $\begin{array}{l}\text { Definition of Corporate Social Responsibility Levels: economic, legal, } \\
\text { ethical, discretionary } \\
\text { Philosophy of Responsiveness Stances: responsive, defensive, } \\
\text { accommodative, proactive } \\
\begin{array}{l}\text { Social Issues involved e.g., Consumerism; Environment; } \\
\text { Discrimination; Product safety; Safety at work; Shareholding }\end{array}\end{array}$ \\
\hline $\begin{array}{l}\text { Wartick and } \\
\text { Cochran } \\
(1985)\end{array}$ & $\begin{array}{l}\text { "The underlying interaction among the } \\
\text { principles of social responsibility, the process } \\
\text { of social responsiveness and the policies } \\
\text { developed to address social issues" } \\
\text { (p. 758) }\end{array}$ & $\begin{array}{l}\text { Corporate Social Responsibilities Levels: economic, legal, ethical, } \\
\text { discretionary } \\
\text { Corporate Social Responsiveness Stances: responsive, defensive, } \\
\text { accommodative, proactive } \\
\text { Social Issues Management Approach: Identification; Analysis; } \\
\text { Response }\end{array}$ \\
\hline $\begin{array}{l}\text { Wood } \\
(1991)\end{array}$ & $\begin{array}{l}\text { "A Business organization's configuration of } \\
\text { principles of social responsibility, processes of } \\
\text { social responsiveness, and policies, programs, } \\
\text { and observable outcomes as they relate to the } \\
\text { firm's societal relationship" } \\
\text { (p. } 693 \text { ) }\end{array}$ & $\begin{array}{l}\text { Principles of Corporate Social Responsibility Levels: Institutional, } \\
\text { Organizational and Individual } \\
\text { Processes of Corporate Social Responsiveness Includes: } \\
\text { Environmental Assessment and Analysis; Stakeholder Managements; } \\
\text { Issues Management Outcomes of Corporate Behavior Combines: } \\
\text { Societal Impacts; Corporate Social Programs and Policies }\end{array}$ \\
\hline $\begin{array}{l}\text { Clarkson } \\
(1995)\end{array}$ & $\begin{array}{l}\text { The ability to manage and satisfy the different } \\
\text { corporate stakeholders }\end{array}$ & $\begin{array}{l}\text { This model identifies specific problems for each of the main } \\
\text { stakeholder categories it distinguishes: Employees; } \\
\text { Owners/Shareholders; Consumers; Suppliers; State; Stakeholders; } \\
\text { Competitors }\end{array}$ \\
\hline
\end{tabular}

Source: Igalens \& Gond (2005, adopted from Fauzi et al., 2010).

The late 90s saw the emergence of the TBL concept, as a new model for measuring ethical, environmental and social responsible behavior of organizations (Elkington, 1994). The TBL paradigm, by emphasizing and integrating the three key dimensions of sustainable development, 'profits, planet and people', forced corporations to widen their circle of responsibility and focus, for the first time, "not just on the economic value that they add, but also on the environmental and social value they add - or destroy" (Elkington, 2004, cited in Miller et al., 2007). The TBL concept "captures the essence of sustainability by measuring the impact of an 
organization's activities on the world ... including both its profitability and shareholder values and its social, human and environmental capital" (Savitz, 2006, cited in Slaper \& Hall, 2011). Proponents of the TBL approach argued that acting in the public interest requires consideration of natural, social, and economic systems (Brown et al, 2006). In his proposition, Elkington argued that 'seven revolutions' are in progress that will drive business and economies towards TBL goals (McEntyre, 2003). The seven revolutions are: (1) Markets; (2) Values - value shifts occurring in the community; (3) Transparency - a shift towards openness; (4) Life cycle technology - the need to manage technologies and associated costs both upstream and downstream in supply terms; (5) Partnerships - which covers supply chain partnerships and building deep partnership with customers and the wider community; (6) Time - the rising importance given to the longer term view and the use of scenarios; (7) Corporate governance. Henderson (2001, cited in Miller et al., 2007) captured the wider essence of the TBL philosophy, when he argued that:

'It identifies a new and enlarged responsibility for businesses today in contributing to both the well-being of society in general and the integrity of the natural environment. To emphasize 'social' responsibility in this way is not to neglect or disregard the interests of the business, but to place them in a wider context, to reassess them'.

The concept of TBL however, does not imply that companies are required to maximize-returns across all the three dimensions of corporate performance (Dutta et al., 2011). The TBLR framework reflects a more comprehensive stakeholder driven reporting mechanism through a comprehensive disclosure of corporate performance to include the environmental, social and economic dimensions of an entity's activities and processes (Dutta et al., 2011). By preparing and disseminating triple bottom line statements, an organization conveys an image of concern and sensitivity to the three dimensions of societal responsibility: economic, environmental, and social (Brown et al., 2006). In this light, it is also almost a truism that firms cannot be successful in the long run if they consistently disregard the interests of key stakeholders (Norman and MacDonald, 2003). According to Clow and Black (2008, cited in Stanislavská et al., 2010), corporations performing activities that are viewed positively, generate quality publicity and clients' loyalty. Companies that try hard to fight unfair practices, pollution, harassment in the workplace and other negatively viewed activities, protect themselves from law suits and negative hearsay from unsatisfied consumers and employees (Clow \& Black, 2008, cited in Stanislavská et al., 2010).

By decent acting in all of these areas, the company may protect itself from the risk of damage of its public image and strengthen positive understanding of its activities by the public (Clow \& Black, 2008, cited in Stanislavská et al., 2010). The apparent novelty of triple bottom line lies in its supporters' contention that the overall fulfillment of obligations to communities, employees, customers, and suppliers (to name but four stakeholders) should be measured, calculated, audited and reported - just as the financial performance of public companies has been for more than a century (Norman and MacDonald, 2003). Triple Bottom Line (TBL) is an approach that aims to report and assess organizational performance in relation to sustainability (Potts, 2004). Jorgensen (2000, cited in Norman \& MacDonald, 2003) opined that triple bottom line is "a valuable management tool - that is, an early warning tool that allows you to react faster to changes in stakeholders' behavior, and incorporate the changes into the strategy before they hit the (real) bottom line".

TBL advocates argue that since an organization's long term viability is dependent on sustaining "profitability" over all three dimensions, they should be measured, reported, and assessed on a periodic basis, in a manner conceptually similar to the current financial reporting model. Norman and MacDonald (2003) outlined the benefits of social reporting for organisations, which could also be inferred to its environmental counterpart:

- (Convergence Claim) Measuring social performance helps improve social performance, and firms with better social performance tend to be more profitable in the long-run.

- (Strong Social-obligation Claim) Firms have an obligation to maximise (or weaker: to improve) their social bottom line - their net positive social impact - and accurate measurement is necessary to judge how well they have fulfilled this obligation.

- (Transparency Claim) The firms have obligations to stakeholders to disclose information about how well it performs with respect to all stakeholders.

\subsection{TBLR: What Is It? and How Is Measured?}

While there is no single universally accepted definition of TBL reporting (G100, 2003), in its broadest sense TBLR can be defined as 'corporate communication with stakeholders that describes the company's approach to managing one or more of the economic, environmental and/or social dimensions of its activities and through providing information on these dimensions' (G100, 2003). Chapman \& Milne (2004) in a sentence defined 
TBLR as 'the measurement, management and reporting of economic, environmental and social performance indicators in a single report'. TBLR is therefore best seen as a process that includes managing, measuring and publicly reporting multi-dimensional performance and integrating it with management process (Potts, 2004). TBLR "defines a company's ultimate worth in financial, social, and environmental terms" (Norman and MacDonald, 2003). Thus, Triple Bottom Line Reporting goes beyond the traditional way of reporting mechanism and encourages businesses to give closer attention to the whole impact of their commercial activities, over and above their financial performance (Dutta et al., 2011). Such reporting tool "responds to all stakeholder demands that companies take part in, be accountable for, and substantiate their membership in society" (Norman and MacDonald, 2003). This view was supported by Osisioma (2010, p. 35) when he opined that 'A firm is not just a bundle of shares, but a collection of relationships between its owners, managers, employees, customers, suppliers and the society as a whole'.

Such a reporting mechanism not only overcomes the existing historical cost based accounting principle but also provides a platform so that the company's performance and its impact can be measured and communicated in a more reliable manner (Dutta et al., 2011). There are no universally accepted standard method/measures for calculating each of the TBL dimensions. This can be viewed as a strength because it allows a user to adapt the general framework to the needs of different entities (businesses or nonprofits), different projects or policies (infrastructure investment or educational programs), or different geographic boundaries (a city, region or country) (Slaper \& Hall, 2011). According to McEntyre (2003) the implementation of a TBL approach is premised on (i) A strategic approach to economic, environmental and social considerations; (ii) The definition of values associated with economic, environmental and social matters; and, (iii) Identifying and measuring performance areas of importance to key stakeholders.

The different phases in the TBLR debate have resulted in its classification into (a) Firm level (b) National level and (c) Global level performance, while the most common measurement dimensions are (a) Economic (b) Environmental and (c) Social dimensions, others include business ethics, corporate governance, human rights, etc.

\subsection{Corporate Performance Perspectives}

Continuous performance is the objective of any organization because only through performance, are organizations able to grow and progress (Gavrea, Ilies \& Stegerean, 2011). The concept of corporate performance is fuzzy, as scholars often agree that there is no universal definition of the concept. Scholars often agree that corporate performance is a function of time and organizational context. Daft (1991, cited in Fauzi et al., 2010) defined corporate performance as the organization's ability to attain its goals by using resources in an efficient and effective manner. Lebans \& Euske (2006, cited in Gavrea et al., 2011) provide a set of definitions to illustrate the concept of organizational performance:

- Performance is a set of financial and nonfinancial indicators which offer information on the degree of achievement of objectives and results;

- Performance is dynamic, requiring judgment and interpretation;

- Performance may be illustrated by using a causal model that describes how current actions may affect future results;

- Performance may be understood differently depending on the person involved in the assessment of the organizational performance (e.g. performance can be understood differently from a person within the organization compared to one from outside);

- To define the concept of performance is necessary to know its elements characteristic to each area of responsibility; and,

- To report an organization's performance level, it is necessary to be able to quantify the results.

Venktrakaman \& Ramanugan (1986, cited in Fauzi et al., 2010) divide corporate performance into operational and financial performances. Operational performance includes: (i) market share, (ii) product quality, and (iii) marketing effectiveness. Financial performance is broken down into two subcategories: (i) market-based performance (e.g., stock price, dividend payout and earnings per share) and (ii) accounting-based performance (e.g., return on assets and return on equity). The concept of corporate performance in accounting literatures refers normally to financial aspects such as profit, return on assets (ROA) and economic value added (EVA), using the nick name of 'the bottom line' (Fauzi et al., 2010). Kaplan and Norton (1992, cited in Fauzi et al., 2010) coined the extended measurement of corporate performance as balanced scorecard, where the core idea is to balance the domination of financial and non-financial aspects in corporate performance. Simons (2000, cited in 
Fauzi et al., 2010) opined that corporate performance is a function of market mechanism reflected in the way the company interacts with the financial, factor and customer product markets. In the financial market, corporate performance strives to satisfy shareholders and creditors in the form of financial indicators. In the factor market, such as suppliers and other production owners, the corporate ability to pay in time and in agreed amount are important in evaluating corporate performance (Fauzi et al., 2010). Finally, from the perspective of customer product market, corporate performance will be evaluated by parties in the market based on the ability of the corporation to deliver value to customers with affordable price which is the net effect, in turn, will be indicated in the corporate revenue (Fauzi et al., 2010).

\section{Research Design \& Methodology}

An exploratory study was carried out to ascertain the perception of corporate stakeholders. The questions were based on a structured five point Likert scale with the following options: Strongly agree (SA); Agree (A); Indifferent (ID); Disagree (D); Strongly disagree (SD) with the associated weights of 5, 4, 3, 2 and 1 respectively. Respondents comprised corporate managers, corporate employees, consumers and investors, distributed across Anambra state in south-eastern Nigeria. The hypotheses formulated were analyzed using Kolmogorov-Smirnoff (K-S), t-Statistic and MRT. The hypotheses formulated and results of empirical data analysis are presented below.

\subsection{Consider Analysis Result for $\mathrm{HI}$}

H1: Triple bottom line disclosures in financial statements would significantly improve product consumption and investment choice among studied respondents.

Table 2. Prospective investors' questionnaire

\begin{tabular}{|c|c|c|c|c|c|c|c|c|}
\hline S/No & Question Description & SA & A & ID & $\mathrm{D}$ & SD & Mean & $\begin{array}{l}\text { Standard } \\
\text { Deviation }\end{array}$ \\
\hline 1 & $\begin{array}{l}\text { I consider product content and other vital information about a product } \\
\text { before purchase }\end{array}$ & 40 & 10 & 2 & 8 & 5 & 4.11 & 1.359 \\
\hline 2 & I will buy a product that meets my health and safety needs & 35 & 12 & 1 & 11 & 6 & 3.91 & 1.444 \\
\hline 3 & $\begin{array}{l}\text { I will buy the product of a company that contributes significant portion of } \\
\text { its profit for social benefits }\end{array}$ & 31 & 23 & 4 & 4 & 3 & 4.15 & 1.093 \\
\hline 4 & $\begin{array}{l}\text { Products that consume or rely much on our natural resources are not } \\
\text { sustainable in the long-run as a result of depleting natural resources }\end{array}$ & 37 & 14 & 8 & 4 & 2 & 4.23 & 1.086 \\
\hline 5 & $\begin{array}{l}\text { A portfolio comprising shares of green corporations is inclined to future } \\
\text { growth and less risk }\end{array}$ & 47 & 10 & 5 & 3 & 0 & 4.55 & .830 \\
\hline 6 & $\begin{array}{l}\text { Stocks of corporations with a CSR strategy are less likely to feel the } \\
\text { impact of a market crash }\end{array}$ & 30 & 28 & 2 & 4 & 1 & 4.26 & .906 \\
\hline 7 & Corporations with a CSR policy protect investor's interest & 39 & 12 & 6 & 4 & 4 & 4.20 & 1.214 \\
\hline 8 & $\begin{array}{l}\text { Investing in sustainable corporations is a strategy to encourage sustainable } \\
\text { development of our society }\end{array}$ & 27 & 17 & 6 & 6 & 9 & 3.72 & 1.442 \\
\hline
\end{tabular}

Source: Field Survey (2012).

Table 3. One-sample Kolmogorov-Smirnov test

\begin{tabular}{lll}
\hline $\mathrm{N}$ & & 65 \\
Normal Parameters ${ }^{\mathrm{a}, \mathrm{b}}$ & Mean & 33.1385 \\
& Std. Deviation & 4.67666 \\
Most Extreme Differences & Absolute & .150 \\
& Positive & .071 \\
Kolmogorov-Smirnov Z & Negative & -.150 \\
Asymp. Sig. (2-tailed) & & 1.207 \\
\hline
\end{tabular}

Notes: a. Test distribution is Normal.

b. Calculated from data.

\section{Decision Rule:}

Using the K-S table, which tests the acceptability of the model from a statistical perspective, the decision rule is as follows: 


$$
\begin{array}{ll}
\mathrm{D}_{\text {calculated }}>\mathrm{D}_{\text {table value }} & \text { Reject the null hypothesis } \\
\mathrm{D}_{\text {table value }}>\mathrm{D}_{\text {calculated }} & \text { Accept the null hypothesis }
\end{array}
$$

Decision: Since, $\mathrm{D}$ calculated $>\mathrm{D}$ table value; $1.207>0.169$ (at 0.05 critical value). Reject the null hypothesis and accept the alternate. Thus, Sustainability reporting would significantly influence product consumption and investment choice among studied respondents.

\subsection{Consider Analysis Result for $\mathrm{H} 2$ \& $\mathrm{H} 3$}

H2: Triple bottom line disclosures in financial statements mitigates litigation risks posed by social and environmental claims on a company

H3: There is a positive connection between triple bottom line disclosures in financial statements and reduced operating costs in organisations

\begin{tabular}{|c|c|c|c|c|c|c|c|c|}
\hline S/No & Question Description & SA & A & ID & $\mathrm{D}$ & SD & Mean & $\begin{array}{l}\text { Standard } \\
\text { Deviation }\end{array}$ \\
\hline 1 & $\begin{array}{l}\text { Adopting a CSR policy is a strategy to safeguard corporations } \\
\text { against future non-compliance costs of environmental and social } \\
\text { practices }\end{array}$ & 13 & 1 & 4 & 3 & 0 & 4.14 & 1.195 \\
\hline 2 & $\begin{array}{l}\text { Sustainability reports significantly reduces external stakeholders' } \\
\text { pressure on corporations to meet CSR practices }\end{array}$ & 12 & 4 & 1 & 3 & 1 & 4.10 & 1.300 \\
\hline 3 & $\begin{array}{l}\text { Triple bottom line reports significantly reduces negative reaction } \\
\text { from host communities }\end{array}$ & 12 & 3 & 4 & 1 & 1 & 4.14 & 1.195 \\
\hline 4 & $\begin{array}{l}\text { Turbulence in the business operating environment of corporations in } \\
\text { the form of negative societal reaction would lead to a declining } \\
\text { profit }\end{array}$ & 14 & 4 & 2 & 1 & 0 & 4.43 & 1.028 \\
\hline 5 & $\begin{array}{l}\text { Sustainability reports serve as an instrument for evaluating social } \\
\text { and environmental impact of corporations and thus, could serve as } \\
\text { an evidence in legal dispute pertaining to the corporations }\end{array}$ & 15 & 3 & 1 & 2 & 0 & 4.48 & .981 \\
\hline 6 & $\begin{array}{l}\text { To meet } 21^{\text {st }} \text { century challenges reduced production cost and } \\
\text { improved profit is imminent }\end{array}$ & 17 & 2 & 2 & 0 & 0 & 4.71 & .644 \\
\hline 7 & $\begin{array}{l}\text { Cost of purchasing new raw materials is generally lower than that of } \\
\text { recycled ones }\end{array}$ & 14 & 3 & 2 & 1 & 1 & 4.33 & 1.155 \\
\hline 8 & $\begin{array}{l}\text { Greening the manufacturing process encourages the identification of } \\
\text { new and better methods of production } \\
\text { leading to cost savings in organisations }\end{array}$ & 10 & 3 & 1 & 2 & 5 & 3.52 & 1.721 \\
\hline 9 & $\begin{array}{l}\text { Shareholders are more apt to change involving green processes than } \\
\text { non-sustainable ones }\end{array}$ & 14 & 3 & 2 & 1 & 1 & 4.33 & 1.155 \\
\hline 10 & $\begin{array}{l}\text { Positive waste disposal and management practices could impact on } \\
\text { overall wellbeing of the community }\end{array}$ & 14 & 5 & 2 & 0 & 0 & 4.57 & .676 \\
\hline 11 & $\begin{array}{l}\text { CSR practices such as recycling and emission reduction are } \\
\text { necessary for a sustainable society which ultimately leads to } \\
\text { sustainable corporate performance }\end{array}$ & 13 & 5 & 1 & 1 & 1 & 4.33 & 1.111 \\
\hline
\end{tabular}

Table 4. Corporate managers' questionnaire

Source: Field Survey (2012).

\begin{tabular}{|c|c|c|c|c|c|c|}
\hline & \multicolumn{6}{|c|}{ Test Value $=0$} \\
\hline & \multirow[b]{2}{*}{$\mathrm{t}$} & \multirow[b]{2}{*}{ df } & \multirow[b]{2}{*}{ Sig. (2-tailed) } & \multirow[b]{2}{*}{ Mean Difference } & \multicolumn{2}{|c|}{$99 \%$ Confidence Interval of the Difference } \\
\hline & & & & & Lower & Upper \\
\hline $\mathrm{H} 3$ & 30.895 & 20 & .000 & 21.09524 & 19.1524 & 23.0380 \\
\hline $\mathrm{H} 2$ & 32.134 & 20 & .000 & 21.28571 & 19.4010 & 23.1705 \\
\hline
\end{tabular}

Table 5. One-sample test

\section{Decision Rule:}

Using the t-Statistic table, which tests the acceptability of the model from a statistical perspective, the decision rule is as follows:
$\mathrm{t}_{\text {calculated }}>\mathrm{t}_{\text {table value }}$
Reject the null hypothesis
$\mathrm{t}_{\text {table value }}>\mathrm{t}_{\text {calculated }}$ Accept the null hypothesis 
H2 Since, $\mathrm{t}_{\text {calculated }}>\mathrm{t}$ table value; $32.134>2.528$ (at 0.01 critical value). Reject the null hypothesis and accept the alternate. Thus, Sustainability reporting mitigates litigation risks posed by social and environmental claims on a company.

H3 Since, $\mathrm{t}_{\text {calculated }}>\mathrm{t}$ table value; $30.895>2.528$ (at 0.01 critical value). Reject the null hypothesis and accept the alternate. Thus, there is a positive connection between sustainability practices and reduced operating costs in organisations.

\subsection{Consider Analysis Result for $\mathrm{H} 4$}

H4: Triple bottom line disclosures in financial statements are positively connected to employee motivation resulting in reduced labour turnover in organisations.

Table 6. Employee questionnaire

\begin{tabular}{|c|c|c|c|c|c|c|c|c|}
\hline $\mathrm{S} / \mathrm{No}$ & Question Description & SA & A & ID & $\mathrm{D}$ & SD & Mean & $\begin{array}{l}\text { Standard } \\
\text { Deviation }\end{array}$ \\
\hline 1 & $\begin{array}{l}\text { Do you consider extrinsic factors such as social and } \\
\text { environmental practices necessary in your work environment }\end{array}$ & 32 & 3 & 10 & 10 & 0 & 4.04 & 1.232 \\
\hline 2 & $\begin{array}{l}\text { Are you inclined to work for corporations with a CSR strategy } \\
\text { safeguarding employees' from exploitation and job } \\
\text { discrimination }\end{array}$ & 30 & 8 & 4 & 10 & 3 & 3.95 & 1.367 \\
\hline 3 & $\begin{array}{l}\text { Are you inclined to remain in a firm constantly revisiting and } \\
\text { modifying its social and environmental practices to suit } \\
\text { current needs }\end{array}$ & 29 & 10 & 9 & 4 & 3 & 4.05 & 1.224 \\
\hline 4 & $\begin{array}{l}\text { Are you willing to sacrifice part of your pay to meet social and } \\
\text { environmental corporate expectations if need be }\end{array}$ & 29 & 12 & 8 & 1 & 5 & 4.07 & 1.260 \\
\hline 5 & $\begin{array}{l}\text { Meeting my corporate needs also contributes to society's } \\
\text { wellbeing as a member of such society }\end{array}$ & 40 & 5 & 2 & 7 & 1 & 4.38 & 1.147 \\
\hline 6 & $\begin{array}{l}\text { Employee involvement in formulating CSR policy is a key to } \\
\text { successful accomplishment of such policies }\end{array}$ & 42 & 6 & 5 & 0 & 2 & 4.56 & .938 \\
\hline
\end{tabular}

Source: Field Survey (2012).

\section{Model Formulation}

$$
\mathrm{Y}=\alpha+\beta \mathrm{X} 1+\beta \mathrm{X} 2+\beta \mathrm{X} 3+\beta \mathrm{X} 4+\beta \mathrm{X} 5
$$

Table 7. Model summary

\begin{tabular}{lllll}
\hline Model & $\mathrm{R}$ & R Square & Adjusted R Square & Std. Error of the Estimate \\
\hline 1 & $.604^{\mathrm{a}}$ & .364 & .300 & 1.031 \\
\hline
\end{tabular}

Note: a. Predictors: (Constant), Employee involvement in formulating CSR policy is a key to successful accomplishment of such policies, Are you willing to sacrifice part of your pay to meet social and environmental corporate expectations if need be, Are you inclined to remain in a firm constantly revisiting and modifying its social and environmental practices, Meeting my corporate needs also contributes to society's wellbeing as a member of such society, Are you inclined to work for corporations with a CSR strategy safeguarding employees' from exploitation and job discrimination.

\begin{tabular}{|c|c|c|c|c|c|c|}
\hline \multicolumn{7}{|c|}{ ANOVA $^{\mathrm{b}}$} \\
\hline \multicolumn{2}{|c|}{ Model } & Sum of Squares & $\mathrm{df}$ & Mean Square & $\mathrm{F}$ & Sig. \\
\hline \multirow[t]{3}{*}{1} & Regression & 29.853 & 5 & 5.971 & 5.618 & $.000^{\mathrm{a}}$ \\
\hline & Residual & 52.074 & 49 & 1.063 & & \\
\hline & Total & 81.927 & 54 & & & \\
\hline
\end{tabular}

Notes: a. Predictors: (Constant), Employee involvement in formulating CSR policy is a key to successful accomplishment of such policies, Are you willing to sacrifice part of your pay to meet social and environmental corporate expectations if need be, Are you inclined to remain in a firm constantly revisiting and modifying its social and environmental practices, Meeting my corporate needs also contributes to society's wellbeing as a member of such society, Are you inclined to work for corporations with a CSR strategy safeguarding employees' from exploitation and job discrimination.

b. Dependent Variable: Do you consider extrinsic factors such as social and environmental practices necessary in your work environment. 


\begin{tabular}{|c|c|c|c|c|c|c|}
\hline \multicolumn{7}{|c|}{ Coefficients $^{\mathrm{a}}$} \\
\hline & & \multicolumn{2}{|c|}{ Unstandardized Coefficients } & \multicolumn{3}{|l|}{$\begin{array}{l}\text { Standardized } \\
\text { Coefficients }\end{array}$} \\
\hline \multicolumn{2}{|c|}{ Model } & B & Std. Error & Beta & $\mathrm{t}$ & Sig. \\
\hline \multirow[t]{6}{*}{1} & (Constant) & -.347 & 1.192 & & -.291 & .772 \\
\hline & $\begin{array}{l}\text { Are you inclined to work for corporations } \\
\text { with a CSR strategy safeguarding } \\
\text { employees' from exploitation and job } \\
\text { discrimination }\end{array}$ & .328 & .111 & .364 & 2.961 & .005 \\
\hline & $\begin{array}{l}\text { Are you inclined to remain in a firm } \\
\text { constantly revisiting and modifying its } \\
\text { social and environmental practices }\end{array}$ & -.023 & .120 & -.023 & -.190 & .850 \\
\hline & $\begin{array}{l}\text { Are you willing to sacrifice part of your } \\
\text { pay to meet social and environmental } \\
\text { corporate expectations if need be }\end{array}$ & .414 & .113 & .423 & 3.653 & .001 \\
\hline & $\begin{array}{l}\text { Meeting my corporate needs also } \\
\text { contributes to society's wellbeing as a } \\
\text { member of such society }\end{array}$ & .239 & .129 & .222 & 1.847 & .071 \\
\hline & $\begin{array}{l}\text { Employee involvement in formulating } \\
\text { CSR policy is a key to successful } \\
\text { accomplishment of such policies }\end{array}$ & .098 & .153 & .075 & .641 & .524 \\
\hline
\end{tabular}

Note: a. Dependent Variable: Do you consider extrinsic factors such as social and environmental practices necessary in your work environment.

\section{Interpretation of Model Results}

Model Summary Table: R square, the coefficient of determination, which is the squared value of the multiple correlation coefficients, indicated a value of .364 (36.4\%). This showed that $36 \%$ approx of the dependent variable (Do you consider extrinsic factors such as social and environmental practices necessary in your work environment) were explained by the independent variables (Employee involvement in formulating CSR policy is a key to successful accomplishment of such policies, Are you willing to sacrifice part of your pay to meet social and environmental corporate expectations if need be, Are you inclined to remain in a firm constantly revisiting and modifying its social and environmental practices, Meeting my corporate needs also contributes to society's wellbeing as a member of such society, Are you inclined to work for corporations with a CSR strategy safeguarding employees' from exploitation and job discrimination). The low R-squared figure clearly indicates the presence of other factors (not considered by the present study) that could explain employee motivation in organizations.

ANOVA Table: Using the ANOVA table, which tests the acceptability of the model from a statistical perspective, the decision rule is as follows:

$$
\begin{array}{ll}
\mathrm{F}_{\text {calculated }}>\mathrm{F}_{\text {table value }} & \text { Reject the null hypothesis } \\
\mathrm{F}_{\text {table value }}>\mathrm{F}_{\text {calculated }} & \text { Accept the null hypothesis }
\end{array}
$$

Decision: Since: $\mathrm{F}_{\text {calculated }}>\mathrm{F}_{\text {table value; }}, 5.618>2.37$ (at 0.05 critical value). Reject the null hypothesis and accept the alternate. Thus, sustainability reporting improves employee motivation and reduce labour turnover in organisations. This decision is strengthened by the fact that the significant value of the F statistics $(0.000)$ is less than 0.05 , which means that the variation explained by the model is not due to chance.

\section{Discussion of Findings, Conclusion and Recommendations}

The results of this study corroborate previous studies (see Fauzi et al., 2010; with varying organizational measurement factors) thus, establishing the relationship between sustainability reporting and organizational performance. More specifically, our findings reveal that:

- Consumers consider product content and other vital information pertaining to a product before purchase and would generally consume more of products that meet their health and safety needs;

- Consumers were also particular about the nature of investment companies are involved in, and would generally buy the products of companies that contribute a substantial amount to society's wellbeing; 
- Investors perceived that green corporations were less likely to feel the impact of a market crash and their stocks inclined to future growth more than non-sustainable ones;

- Managers opined that while business turbulence caused by negative societal reaction could distort profit margin, sustainability reports significantly reduces stakeholders pressure and negative reactions from host communities (as was the case in the Niger Delta region);

- Employees as part of the society agreed that satisfying their individual needs could ultimately satisfy corporate needs and society needs, thus, were also willing to contribute part of their pay for social welfare;

Predicated upon the above findings, the nexus of sustainability reporting on corporate performance is established. The current speed of the globalization process facilitated by rapid advances in information technology (ICT) has posed a serious challenge for $21^{\text {st }}$ century corporations. Thus, corporate survival is a function of the extent to which organizations react positively to economic and corporate troughs. Consequently, the study recommends that since sustainable performance is the goal of any organization a sustainable strategy should be adopted by organizations'.

One such strategy is sustainability reporting aimed at promoting the transparency and accountability level of organizations. This should generally follow a CSR policy in such organization. Literature and data analysis saw a need for employee involvement in formulating CSR policies. This will ultimately lead to its acceptance at the top, middle and low levels of management. Finally, a framework for such reporting procedure needs to be enacted in the context of developing nations and Nigeria in particular. This will ensure the inclusion of elements peculiar to our operating and business environment. Figure 2 below depicts the possible relationship between TBL disclosures and corporate performance:

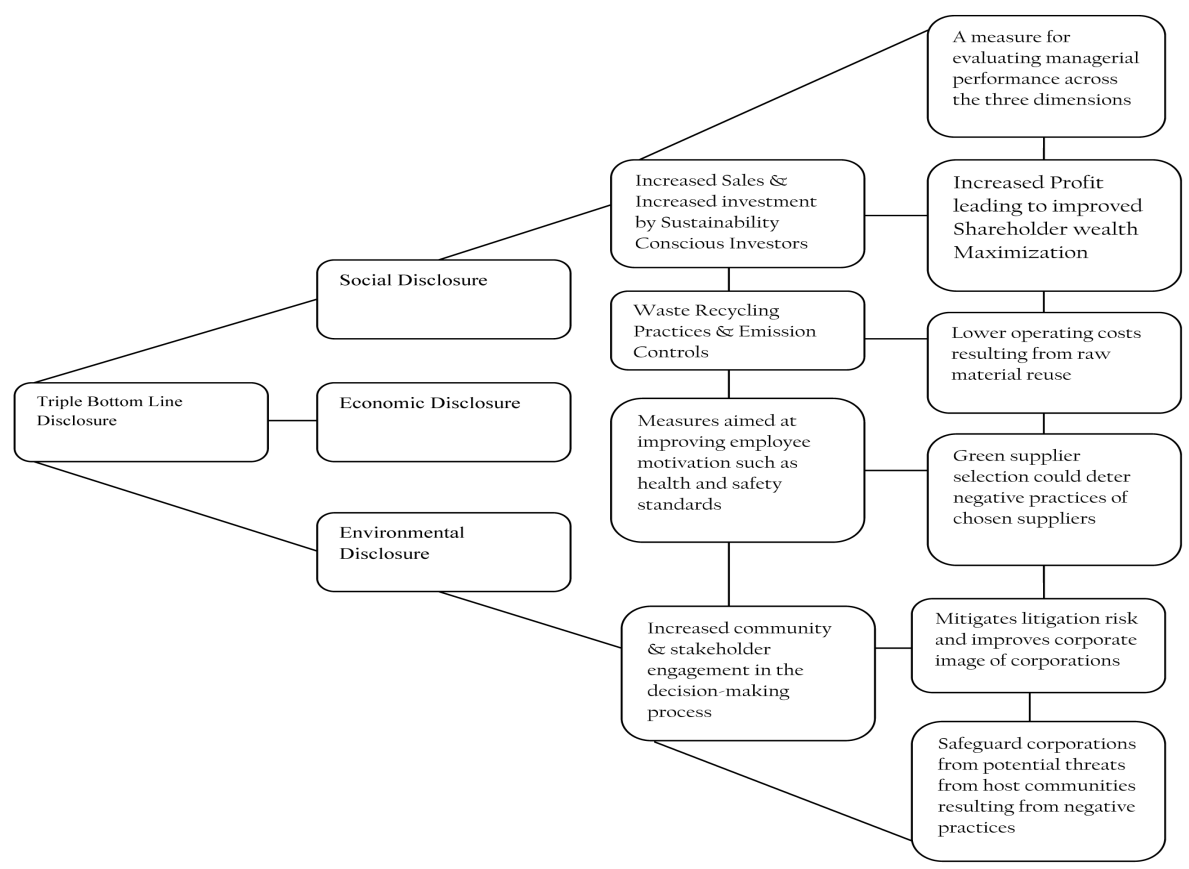

Figure 2. The possible relationship between TBL disclosures and corporate performance

\section{References}

Adams, C. A., Hill, W. Y., \& Roberts, C. B. (1998). Corporate Social Reporting Practices in Western Europe: Legitimating Corporate Behaviour. British Accounting Review, 30(1), 1-22. http://dx.doi.org/10.1006/bare.1997.0060

Ball, A., Owen, D. L., \& Gray, R. H. (2000). External transparency or internal capture? The role of third party statements in adding value to corporate environmental reports. Business Strategy and the Environment, 9(1), 1-23. http://dx.doi.org/10.1002/(SICI)1099-0836(200001/02)9:1<1::AID-BSE227>3.0.CO;2-H 
Beder, S. (1997). Global Spin: The corporate assault on environmentalism. London: Green Books.

Brown, D., Dillard, J., \& Marshall, R. S. (2006). Triple Bottom Line: A business metaphor for a social construct. Retrieved November 22, 2012 from http://www.sba.pdx.edu/faculty/darrellb/dbaccess/MIM/TBL.pdf

Casanova, L. (2010). Corporate Social Responsibility and Latin American Multinationals: Is Poverty a Business Issue? Universia Business Review, 132-145. Retrieved from ubr.universia.net/pdfs_web/25010-07.pdf

Chapman, R., \& Milne, M. J. (2004). The Triple Bottom Line: How New Zealand Companies Measure Up. Corporate Environmental Strategy: International Journal for Sustainable Business, 11(2), 37-50.

Da Piedade, L., \& Thomas, A. (2006). The case for corporate responsibility: an exploratory study. SA Journal of Human Resource Management, 4(2), 65-74.

Doane, D. (2002). Market Failure: The Case for Mandatory Social \& Environmental Reporting. The New Economics Foundation, London.

Dobson, A. (1998). Justice and the Environment: Conceptions of Environmental Sustainability and Dimensions of Social Justice. Oxford: Oxford University Press.

Dutta, S. (2011). Triple Bottom Line Reporting: need of the hour. The Alternative, X(1), 62-74.

Dutta, S. (2012). Triple Bottom Line Reporting: An Indian Perspective. Interdisciplinary Journal of Contemporary Research in Business, 3(12), 652-659.

Dutta, S. et.al. (2011). Triple Bottom Line Reporting: an innovative accounting initiative. International Journal on Business, Strategy and Management, 1(1), 1-13.

Dyllick, T., \& Hockerts, K. (2002). Beyond the Business Case for Corporate Sustainability. Business Strategy and the Environment, 11, 130-141. http://dx.doi.org/10.1002/bse.323

Elkington, J. (1997). Cannibals with Forks: The triple bottom line of 21st Century Business. Oxford: Capstone Publishing.

Fauzi, H., Svensson, G., \& Rahman, A. (2010). Triple Bottom Line" as "Sustainable Corporate Performance": A Proposition for the Future. Sustainability, 2(5), 1345-1360. http://dx.doi.org/10.3390/su2051345

Gavrea, C., Ilies, L.. \& Stegerean, R. (2011). Determinants of organizational performance: The case of Romania. Management \& Marketing, 6(2), 285-300.

Gilkison, B. (1995). An Annual Report Saying "We Care". Chartered Accountants Journal of New Zealand, November, 8-17.

Gilkison, B. (1996). Missing the Green Light. Chartered Accountants Journal of New Zealand, October, 66-70.

Gilkison, B. (1997). Environmental Accountability: Award Winners Show the Way - Others Need a Push. Chartered Accountants Journal of New Zealand, September, 57-61.

Gilkison, B. (1998). The Best Get Better. Chartered Accountants Journal of New Zealand, August, 57-61.

Gilkison, B., \& Ensor, J. (1999). Desperately Seeking Volunteers. Chartered Accountants Journal of New Zealand, October, 32-36.

Global Reporting Initiative (GRI). (2002). Draft 2002 Sustainability Reporting Guidelines, April2002, GRI.

Gordon, L. W., \& Reddy, K. (2010). The Effect of Sustainability Reporting on Financial Performance: An Empirical Study Using Listed Companies. Journal of Asia Entrepreneurship and Sustainability, 6(2), 19-42.

Gray, R. H. (1992). Accounting and Environmentalism: An Exploration of the Challenge of Gently Accounting for Accountability, Transparency and Sustainability. Accounting, Organisations \& Society, 9(2), 399-426. http://dx.doi.org/10.1016/0361-3682(92)90038-T

Gray, R. H. (2001). Thirty Years of Social Accounting: What (if Anything) Have We Learnt? Business Ethics: A European Review, 10, 9-15. http://dx.doi.org/10.1111/1467-8608.00207

Gray, R. H., \& Milne, M. J. (2002). Sustainability Reporting: Who's Kidding Whom? Chartered Accountants Journal of New Zealand, July, 66-70.

Gray, R., \& Bebbington, J. (2000). Environmental Accounting, Managerialism and Sustainability. Advances in Environmental Accounting \& Management, 1, 1-44. http://dx.doi.org/10.1016/S1479-3598(00)01004-9 
Ho, L. C. J., \& Taylor, M. E. (2007). An Empirical Analysis of Triple Bottom-line Reporting and its Determinants: Evidence from the United States and Japan. Journal of International Financial Management and Accounting, 18(2), 123-150. http://dx.doi.org/10.1111/j.1467-646X.2007.01010.x

Hubbard, G. (2009). Measuring Organizational Performance. Beyond the Triple Bottom line. Business, Strategy \& the Environment, 19, 177-191. http://dx.doi.org/10.1002/bse.564

Igalens, J., \& Gond, J. P. (2005). Measuring corporate social performance in France: A critical and empirical analysis of ARESE data. Journal of Business Ethics, 56, 131-148. http://dx.doi.org/10.1007/s10551-004-3529-7

Isaksson, R. (2005). Economic Sustainability and the Cost of Poor Quality. Corporate SocialResponsibility and Environmental Management, 12, 197-209. http://dx.doi.org/10.1002/csr.85

Jones, K., \& Alabaster, T. (1999). Critical Analysis of Corporate Environmental Reporting. Journal of Environmental Assessment Policy and Management, 1, 27-60. http://dx.doi.org/10.1142/S1464333299000041

Kolk, A. (1999). Evaluating Corporate Environmental Reporting. Business Strategy and the Environment, 8, 225-237. http://dx.doi.org/10.1002/(SICI)1099-0836(199907/08)8:4<225::AID-BSE206>3.0.CO;2-4

Kouloudis, A., Evangelinos, K., \& Kourmousis, F. (2009). Development of an Evaluation Methodology for Triple Bottom Line Reports Using International Standards on Reporting. Environmental Management, 44, 298-311. http://dx.doi.org/10.1007/s00267-009-9305-9

KPMG. (2002). Triple-Bottom-Line Reporting: KPMG Guide to Producing an Annual Report. Auckland, New Zealand: KPMG.

McEntyre, R. (2003). Triple Bottom Line and the Community Library. Retrieved November 21, 2012 from www.mcentyre.com.au/articles/triple_bottom_line.pdf

Miller, E., Buys, L., \& Summerville, J. (2007). Quantifying the social dimension of triple bottom line: Development of a framework and indicators to assess the social impact of organisations. International Journal of Business Governance and Ethics, 3(3), 223-237.

Milne, M. J. (1996). On Sustainability, the Environment and Management Accounting. Management Accounting Research, 7(1), 135-161. http://dx.doi.org/10.1006/mare.1996.0007

Milne, M. J., \& Owen. D. L. (1999). European Environmental Reporting Practice Sets the Standard: Can New Zealand Meet the Challenge? Chartered Accountants Journal of New Zealand, October, 37-40

Milne, M. J., Owen, D. L., \& Tilt, C. A. (2001). Corporate Environmental Reporting: Are New Zealand Companies Being Left Behind? University of Auckland Business Review, 3(2), 24-36.

Mish, J., \& Scammon, D. L. (2010). Principle-Based Stakeholder Marketing: Insights from Private Triple-Bottom-Line Firms. Journal of Public Policy \& Marketing, 29(1), 12-26. http://dx.doi.org/10.1509/jppm.29.1.12

Mitchell, M., Curtis, A., \& Davidson, P. (2008). Evaluating the Process of Triple Bottom Line Reporting; Increasing the Potential for Change. Local Environment, 13(2), 67-80. http://dx.doi.org/10.1080/13549830701581937

Morhardt, J. E. (2001). Scoring Corporate Environmental Reports for Comprehensiveness: A Comparison of Three Systems. Environmental Management, 26(6), 881-892. http://dx.doi.org/10.1007/s002670010196

Morhardt, J. E., Baird, S., \& Freeman, K. (2002). Scoring Corporate Environmental and Sustainability Reports Using GRI 2000, ISO 14031 and Other Criteria. Corporate Social Responsibility and Environmental Management, 9, 215-233. http://dx.doi.org/10.1002/csr.26

Norman, W., \& MacDonald, C. (2004). Getting to the bottom of the "triple bottom line". Business Ethics Quarterly, 14(2), 243-262. http://dx.doi.org/10.5840/beq200414211

Osisioma, B. C. (2010). Global Financial Crisis: Impact on the Changing Face of Accountancy Profession. Frontier Lecture Series 001, Department of Accountancy: Nnamdi Azikiwe University.

Owen, D. L., \& Swift, T. (2000). Social Accounting, Reporting and Auditing: Beyond the Rhetoric. Business Ethics: A European Review, 10, 4-8. http://dx.doi.org/10.1111/1467-8608.00206

Owen, D., Gray. R. H., \& Bebbington, J. (1997). Cosmetic Irrelevance or Radical Agenda for Change? Asia-Pacific Journal of Accounting, 4(2), 175-198. http://dx.doi.org/10.1080/10293574.1997.10510519 
Owen, D., Swift, T., \& Hunt, K. (2001). Questioning the Role of Stakeholder Engagement in Social and Ethical Accounting, Auditing and Reporting. Accounting Forum, 25(3), 264-282. http://dx.doi.org/10.1111/1467-6303.00066

Owen, D., Swift, T., Humphrey, C., \& Bowerman, M. (2000). The New Social Audits: Accountability, Managerial Capture or the Agenda of Social Champions? The EuropeanAccounting Review, 9(1), 81-98. http://dx.doi.org/10.1080/096381800407950

Painter-Morland, M. (2006). Triple Bottom-Line Reporting as Social Grammar: Integrating Corporate Social responsibility and Corporate Codes of Conduct. Business Ethics: A European Review, 15(4), 352-364. http://dx.doi.org/10.1111/j.1467-8608.2006.00457.x

Reddy, K., \& Gordon, L. W. (2010). The Effect of Sustainability Reporting on Financial Performance: An Empirical Study Using Listed Companies. Journal of Asia Entrepreneurship and Sustainability, VI(2), $19-42$.

Rogers, M., \& Roberta, R. (2001). The Triple Bottom Line for Sustainable Community Development. Local Environment, 6(3), 279-289. http://dx.doi.org/10.1080/13549830120073275

Rossi, M. S., Brown, H. S., \& Baas, L. W. (2000). Editorial—Leaders in Sustainable Development: How Agents of Change Define the Agenda. Business Strategy and the Environment, 9, 273-286. http://dx.doi.org/10.1002/1099-0836(200009/10)9:5<273::AID-BSE254>3.0.CO;2-Q

Slaper, T., \& Hall, T. (2011). The Triple Bottom Line: What Is It and How Does It Work? INDIANA BUSINESS REVIEW, 86(1), 4-8.

Stanislavská, L., Margarisová, K., \& Štastná, K. (2010). International Standards of Corporate Social Responsibility. Agris on-line Papers in Economics and Informatics, II(4), 63-72.

UNEP/SustainAbility. (1994). Company Environmental Reporting: A Measure of the Progress Business \& Industry Towards Sustainable Development. London.

UNEP/SustainAbility. (1996). Engaging Stakeholders: The Benchmark Survey. London.

UNEP/SustainAbility. (1997). The 1997 Benchmark Survey: The Third International Progress Report on Company Environmental Reporting. London.

UNEP/SustainAbility. (2000). The Global Reporters: the 2000 Benchmark Survey. London.

UNEP/SustainAbility. (2002). Trust Us: The Global Reporters 2002 Survey of Corporate Sustainability. London.

Venktrakaman, N., \& Ramanugan, V. (1986). Measurement of business performance in strategy research: A comparative of approach. Academy of Management Review, 11, 801-814.

Waddock, S. A., Bodwell, C., \& Graves, S. B. (2002). Responsibility: The new business imperative. Academy of Management Executive, 16(2), 132-150. http://dx.doi.org/10.5465/AME.2002.7173581

Wang, L., \& Lin, L. (2007). A Methodology Framework for the Triple Bottome Line Accounting and Management of Industry Enterprises. International Journal of Production Research, 45(5), 1063-1088. http://dx.doi.org/10.1080/00207540600635136

WBCSD. (2010). Vision 2050: The new agenda for business: World Business Council for Sustainable Development.

WCED. (1987). Our Common Future: the Brundtland Report.

Welford, R. J. (1998). Editorial-Corporate Environmental Management, Technology and Sustainable Development: Postmodern Perspectives and the Need for a Critical Research Agenda. Business Strategy and the Environment, $1-12$. http://dx.doi.org/10.1002/(SICI)1099-0836(199802)7:1<1::AID-BSE132>3.0.CO;2-7

Wheeler, D., \& Sillanpäa, M. (1997). The Stakeholder Corporation. London: Pitman.

Zadek, S. (2004). The path to corporate responsibility. Harvard Business Review, December, 1-8. 